\title{
FEKUNDITAS DAN DIAMETER TELUR IKAN TERBANG DI PERAIRAN SELAT MAKASSAR DAN UTARA BALI
}

\author{
Firman Ferdiansyah'1) dan Augy Syahailatua ${ }^{2)}$ \\ 1) Peneliti pada Fakultas Perikanan dan IImu Kelautan-Universitas Padjajaran, Bandung \\ 2) Peneliti pada Pusat Penelitian Oseanografi-Lembaga IImu Pengetahuan Indonesia, Ancol-Jakarta \\ Teregistrasi I tanggal: 21 September 2010; Diterima setelah perbaikan tanggal: 19 Nopember 2010; \\ Disetujui terbit tanggal: 30 Nopember 2010
}

\begin{abstract}
ABSTRAK
Fekunditas dan diameter telur ikan merupakan bagian dari studi reproduksi biologi perikanan. Aspek ini dikaji dari tiga jenis ikan terbang, yaitu Cheilopogon cyanopterus, Hirundichthys oxycephalus, dan Parexocoetus mento yang dikumpulkan dari hasil tangkapan nelayan dengan jaring insang hanyut di perairan Takalar (Selat Makassar) dan Pemuteran (Bali Utara). Jumlah contoh yang diamati 58 gonad ikan betina yang berada pada tingkat kematangan gonad III dan IV. Fekunditas tertinggi dimiliki oleh Parexocoetus mento, namun rata-rata fekunditas tertinggi dimiliki oleh jenis Hirundichthys oxycephalus. Korelasi antara fekunditas dan panjang total ikan memiliki tingkat keeratan yang rendah, sedangkan korelasi antara fekunditas dan bobot gonad memiliki tingkat keeratan yang kuat. Distribusi diameter telur ikan pada ketiga jenis ikan terbang ini tidak menunjukan perbedaan yang signifikan, namun secara umum diameter telur pada tingkat kematangan gonad III $(0,33-2,21 \mathrm{~mm})$ lebih kecil dari pada tingkat kematangan gonad IV $(0,45-2,36 \mathrm{~mm})$. Penelitian ini memberikan indikasi bahwa terdapat variasi fekunditas dan diameter telur antar jenis ikan terbang, serta lokasi penangkapan ikan terbang yang dilakukan oleh nelayan lokal saat ini merupakan daerah pemijahan.
\end{abstract}

KATAKUNCI: fekunditas, telur ikan, ikan terbang, Selat Makassar, Bali Utara

ABSTRACT: $\quad$ Flyingfish fecundity and egg diameter in the waters of Makassar Strait and North Bali. By: Firman Ferdiansyah and Augy Syahailatua

Fish fecundity and egg diameter are essential aspects in the study of fishery biological reproductive. These two aspects were observed on three species of fyingfish Cheilopogon cyanopterus, Hirundichthys oxycephalus, and Parexocoetus mento which collected from fishermen caught used a drift gillnet in the waters of Takalar (Makassar Strait) and Pemuteran (north Bali). Numbers of samples examined were 58 gonads of flyingfish at the third (develop) and fourth (mature) maturity stages. The higest fecundity was in the gonad of Parexocoetus mento, however the highest of fecundity mean was in Hirundichthys oxycephalus. The correlation between fecundity and total length shows a weak relationship, however the correlation between fecundity and gonad weight show a strong relationship. Egg diameter of these three flyingfish species had no significant different, but generally egg diameter of develop gonad $(0.33-2.21 \mathrm{~mm})$ was smaller than the mature one $(0.45-2.36 \mathrm{~mm})$. This study indicates variability in fecundity and eeg diameter among flyingfish species. In addition, the fishing grounds also indicates spawing grounds.

\section{KEYWORDS: $\quad$ fecundity, fish eggs, flyingfish, Makassar Straits, North Bali}

\section{PENDAHULUAN}

Ikan terbang dikenal dengan nama lokal torani atau tuing-tuing, merupakan salah satu komoditi perikanan yang bernilai ekonomis penting, karena selain menjadi ikan konsumsi, telurnya menjadi komoditi ekspor yang bernilai tinggi. Ekspor telur ikan terbang sudah dimulai sejak tahun 1968 dengan negara tujuan Jepang, dan pada periode tahun 1971-1981 ekspor telur ikan terbang terus meningkat setiap tahunnya rata-rata $30 \%$ (Sihotang, 2004). Banyaknya permintaan ekspor telur ikan terbang menjadikan tingginya harga telur ikan terbang, harga telur ikan terbang di Makasar sejak tahun 1998-2002 berkisar antara Rp.150.000-300.000/ kg, sedangkan harga di Jepang pada tahun 1998-2001 berkisar antara 25-50 US \$ per kg, hal ini menyebabkan terjadinya peningkatan penangkapan telur ikan terbang (Syahailatua et al., 2008).

Selat Makassar dan Laut Flores merupakan wilayah eksploitasi telur ikan terbang sejak 30 tahun lalu (Syahailatua, 2006; Syahailatua et al., 2008), dan sampai saat ini menjadi lokasi utama penghasil telur ikan terbang di Indonesia, namun dengan kecenderungan produksi yang menurun. Dugaan adanya eksploitasi telur ikan terbang yang berlebihan tentunya beralasan dengan melihat potensi produksi yang menurun dalam 30 tahun terakhir yang telah 
mencapai 50\% (Syahailatua, 2006; Syahailatua et al., 2008). Dengan demikian upaya pengelolaan perikanan ikan terbang di Indonesia, khususnya di Selat Makassar dan Laut Flores mendapat perhatian yang cukup besar. Sejalan dengan upaya pengelolaan ini, maka dibutuhkan penelitian biologi perikanan yang terkait dengan reproduksi ikan terbang. Aspek kajian fekunditas dan diameter telur menjadi fokus penelitian biologi perikanan ikan terbang untuk mengkaji kemampuan ikan terbang menghasilkan telur dan ukuran telurnya. Informasi ini dapat dipergunakan untuk memprediksi rekruitmen dan pemulihan stok perikanan ikan terbang.

\section{BAHAN DAN METODE}

Contoh telur ikan terbang yang dipergunakan dalam studi ini diperiksa dari gonada pada tingkat perkembangan III dan IV yang berasal dari jenis Cheilopogon cyanopterus, Hirundichthys oxycephalus, dan Parexocoetus mento. Informasi lengkap tentang contoh ikan dapat dilihat pada Tabel 1. Contoh ikan diperoleh dari perairan Takalar (Selat Makasar) pada bulan Maret sampai Juli 2005, dan perairan Pemuteran (Bali utara) pada bulan Oktober sampai Desember 2005 (Gambar 1).

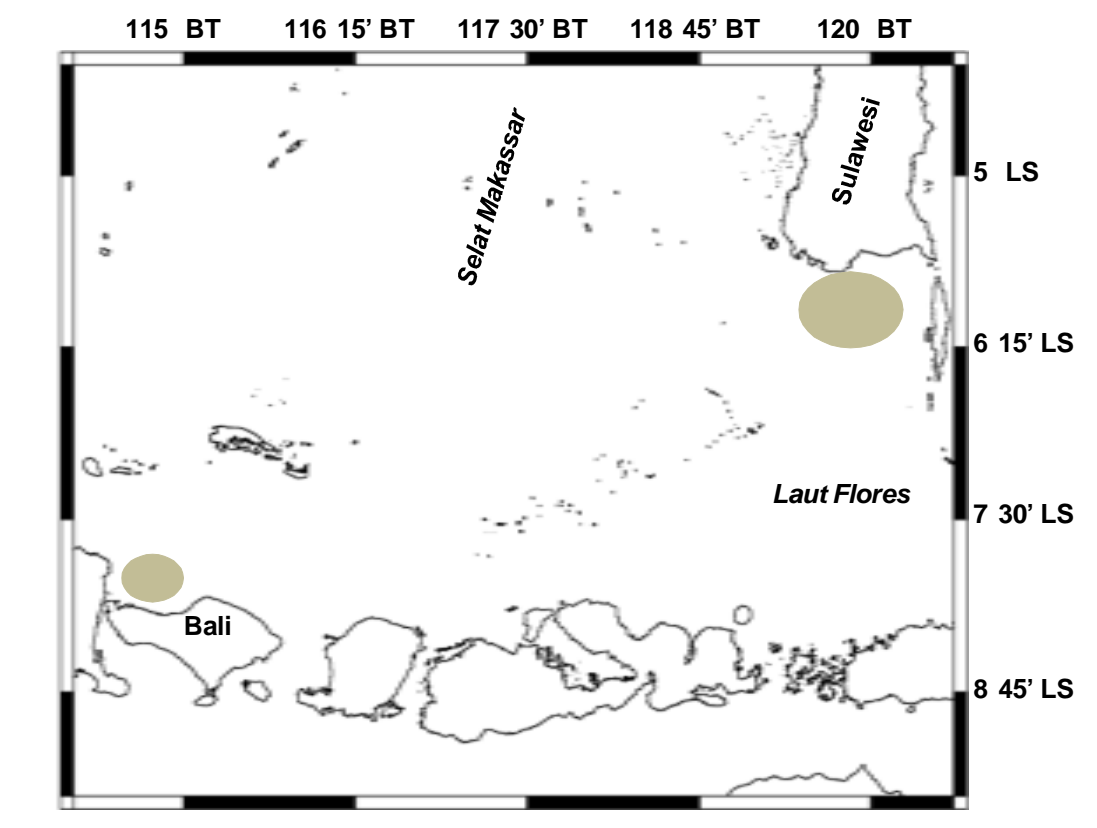

Gambar 1. Lokasi pengumpulan contoh ikan terbang di perairan Selat Makassar dan Bali Utara (bagian yang berwarna abu-abu).

Figure 1. Sampling locations of flyingfish in the waters of Makassar Strait and north Bali (grey spots).

Contoh ikan diperoleh dari nelayan dengan menggunakan jaring insang hanyut (drift gillnet). Setelah didaratkan, contoh diawetkan dengan larutan formalin $10 \%$. Selanjutnya, contoh dikirim ke laboratorium biologi laut di Pusat Penelitian Oseanografi-Lembaga Ilmu Pengetahuan Indonesia, Jakarta, untuk analisis yang lebih komprehensif.

Contoh ikan yang telah dibawa ke laboratorium diukur panjang totalnya dengan caliperyanng memiliki ketelitian $0,1 \mathrm{~mm}$ dan bobot totalnya ditimbang dengan menggunakan timbangan O'hauss yang memiliki ketelitian $0,1 \mathrm{~g}$, dan kemudian dibedah pada bagian perut untuk diamati organ reproduksi (gonad) dan penentuan tingkat kematangan gonad. Pengamatan tingkat kematangan gonad secara morfologi didasarkan atas klasifikasi yang dimodifikasi dari Cassie (Effendie, 1979). Lewat tahapan ini, maka dapat diketahui ikan terbang betina dengan tingkat kematangan gonad III atau IV yang merupakan ikan-ikan yang siap memijah. Selanjutnya, fekunditas dihitung dari ikan betina yang memiliki tingkat kematangan gonad III dan IV.

Perhitungan fekunditas dilakukan dengan menggunakan dua tahap, yaitu tahap pertama adalah cara mendapatkan telur dan tahap kedua adalah cara mengeluarkan telur. Cara mendapatkan telur yaitu mengambil telur dari ikan induk dengan mengangkat seluruh gonadnya dari dalam perut ikan yang telah diawetkan. Cara menghitung telur, yaitu dengan menggunakan metode gravimetrik (Effendie, 2002), di mana gonad dan sub gonad ditimbang untuk menentukan bobotnya masing-masing. Bagian sub 
gonad adalah bagian anterior, median, dan posterior dari gonad yang kemudian diambil telur-telurnya dan dihitung jumlahnya. Data ini dipergunakan untuk perhitungan fekunditas, dengan formula (Effendie, 2002):

$$
\mathrm{F}=\underline{\mathrm{G}} \times \mathrm{N}
$$

di mana:

$$
\begin{aligned}
& F=\text { fekunditas (butir) } \\
& G=\text { bobot gonad }(\mathrm{g}) \\
& \mathrm{Q}=\text { bobot sub gonad }(\mathrm{g}) \\
& \mathrm{N}=\text { jumlah telur pada sub gonad (butir) }
\end{aligned}
$$

Kemudian, relasi panjang total-fekunditas, dan bobot total fekunditas ditunjukan dalam suatu bentuk rumus umum (Hile, 1963 dalam Effendie, 1979), yaitu:

$$
\begin{aligned}
& F=a L^{b} \text { atau } \log F=\log a+b \log L \ldots \\
& F=a W^{b} \text { atau } \log F=\log a+b \log W
\end{aligned}
$$

$$
\begin{array}{ll}
\text { di mana: } & \\
\mathrm{F} & =\text { fekunditas }(\text { butir telur) } \\
\mathrm{L} & =\text { panjang total ikan }(\mathrm{cm}) \\
\mathrm{W} & =\text { bobot gonad total }(\mathrm{g}) \\
\mathrm{a} \text { dan } \mathrm{b} & =\text { konstanta }
\end{array}
$$

Ukuran telur yang diamati adalah diameternya. Pada setiap gonad yang berada pada tingkat kematangan gonad III dan IV diambil contoh telur dari tiga bagian yaitu lobus anterior, median, dan posterior gonad, kemudian dari masing-masing bagian tersebut diambil sub contoh telur dan diukur diameternya

\begin{tabular}{|c|c|c|c|c|}
\hline Jenis/Species & Lokasi/Site & Tanggal/Date & TKG III/Developed & TKG IV/Mature \\
\hline \multirow[t]{3}{*}{ Cheilopogon cyanopterus } & Selat Makasar & $08 / 05 / 2005$ & 4 & 8 \\
\hline & & $27 / 06 / 2005$ & 1 & 1 \\
\hline & & $30 / 07 / 2005$ & 1 & 2 \\
\hline \multirow[t]{2}{*}{ Hirundichthys oxycephalus } & Selat Makasar & $27 / 06 / 2005$ & 5 & 5 \\
\hline & & $30 / 07 / 2005$ & 4 & 7 \\
\hline \multirow[t]{4}{*}{ Parexocoetus mento } & Selat Makasar & $27 / 06 / 2005$ & 1 & - \\
\hline & Bali Utara & 02/10/2005 & 7 & 1 \\
\hline & & $10 / 11 / 2005$ & 5 & 1 \\
\hline & & 24/12/2005 & 4 & 1 \\
\hline \multicolumn{3}{|c|}{$\sum$ total contoh } & 32 & 26 \\
\hline
\end{tabular}
dengan menggunakan mikroskop yang dilengkapi mikrometer okuler.

\section{HASIL DAN BAHASAN}

\section{Kondisi Contoh Gonad}

Contoh ikan betina yang diperoleh pada tingkat kematangan gonad III dan IV, masing-masing 55,2 dan 44,8\% (Tabel 1). Hal ini dapat memberikan indikasi bahwa periode penelitian berada pada musim pemijahan.

\begin{tabular}{|c|c|c|c|c|}
\hline \multirow{2}{*}{ Jenis/Species } & \multirow{2}{*}{$\sum$ ind $/ n$} & \multicolumn{3}{|c|}{ Jumlah telur/Number of eggs } \\
\hline & & Min. (butir/eggs) & Max. (butir/eggs) & Mean ( \pm SD) \\
\hline Cheilopogon cyanopterus & 17 & 2.704 & 7.919 & $4.291( \pm 1.250)$ \\
\hline Hirundichthys oxycephalus & 21 & 2.899 & 8.862 & $5.505( \pm 1.851)$ \\
\hline Parexocoetus mento & 20 & 3.018 & 9.410 & $4.596( \pm 1.723)$ \\
\hline
\end{tabular}

Tabel 1. Komposisi contoh gonad tingkat kematangan gonad III dan IV yang diamati selama penelitian ini Table 1. Gonad sample composition at third and fourth maturity stages observed during this study

\section{Fekunditas}

Terdapat variasi fekunditas antar ketiga jenis ikan terbang (Tabel 2 dan Gambar 2). Dari contoh ketiga jenis ikan terbang, fekunditas tertinggi dimiliki oleh Parexocoetus mento, namun rata-rata fekunditas tertinggi dimiliki oleh jenis Hirundichthys oxycephalus.

Tabel 2. Variasi fekunditas dari tiga jenis ikan terbang yang diperoleh selama pengamatan. Tabel 2. Fecundity variability of three flyingfish species obtained during this study. 


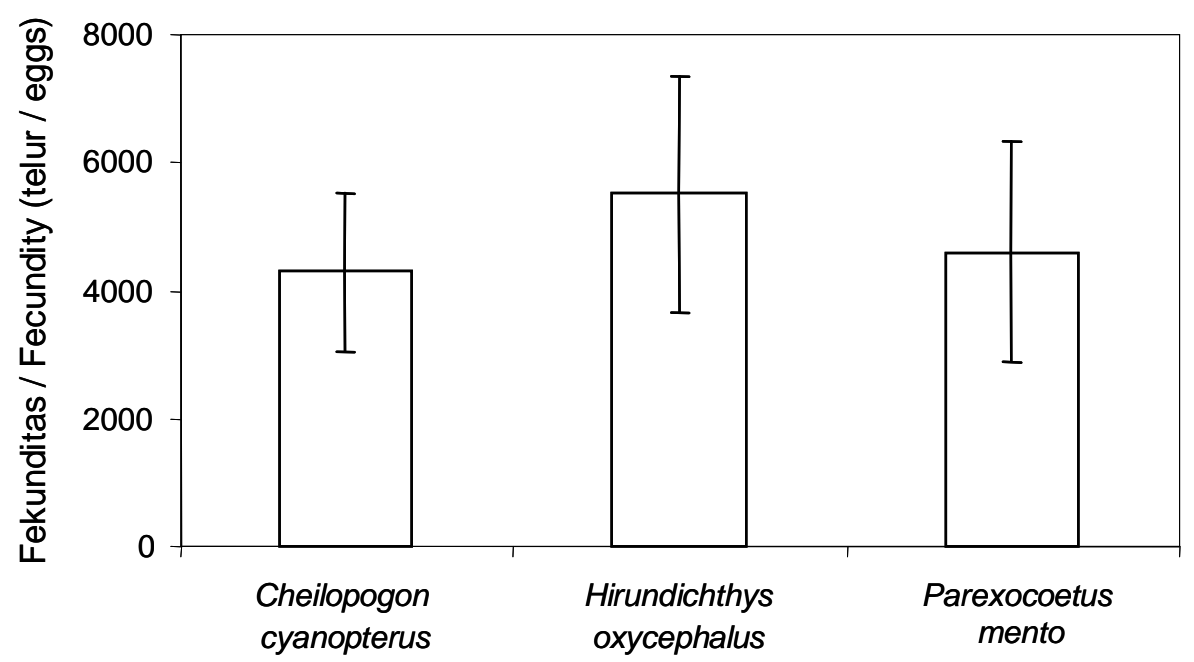

Gambar 2. Fekunditas rata-rata dari tiga jenis ikan terbang.

Figure 2. Fecundity meand of three flyingfish species

Jika fekunditas dengan panjang ikan dikorelasikan, maka hubungan regresi dalam Gambar 3. Terdapat korelasi antara fekunditas dan panjang ikan, namun keeratan korelasinya rendah. Hal ini membuktikan bahwa ukuran panjang ikan tidak menentukan fekunditas, berarti ikan-ikan yang tertangkap kemungkinan ikan-ikan yang sudah dewasa dan mencapai ukuran panjang maksimum, dan juga bukan baru pertama kali memijah.

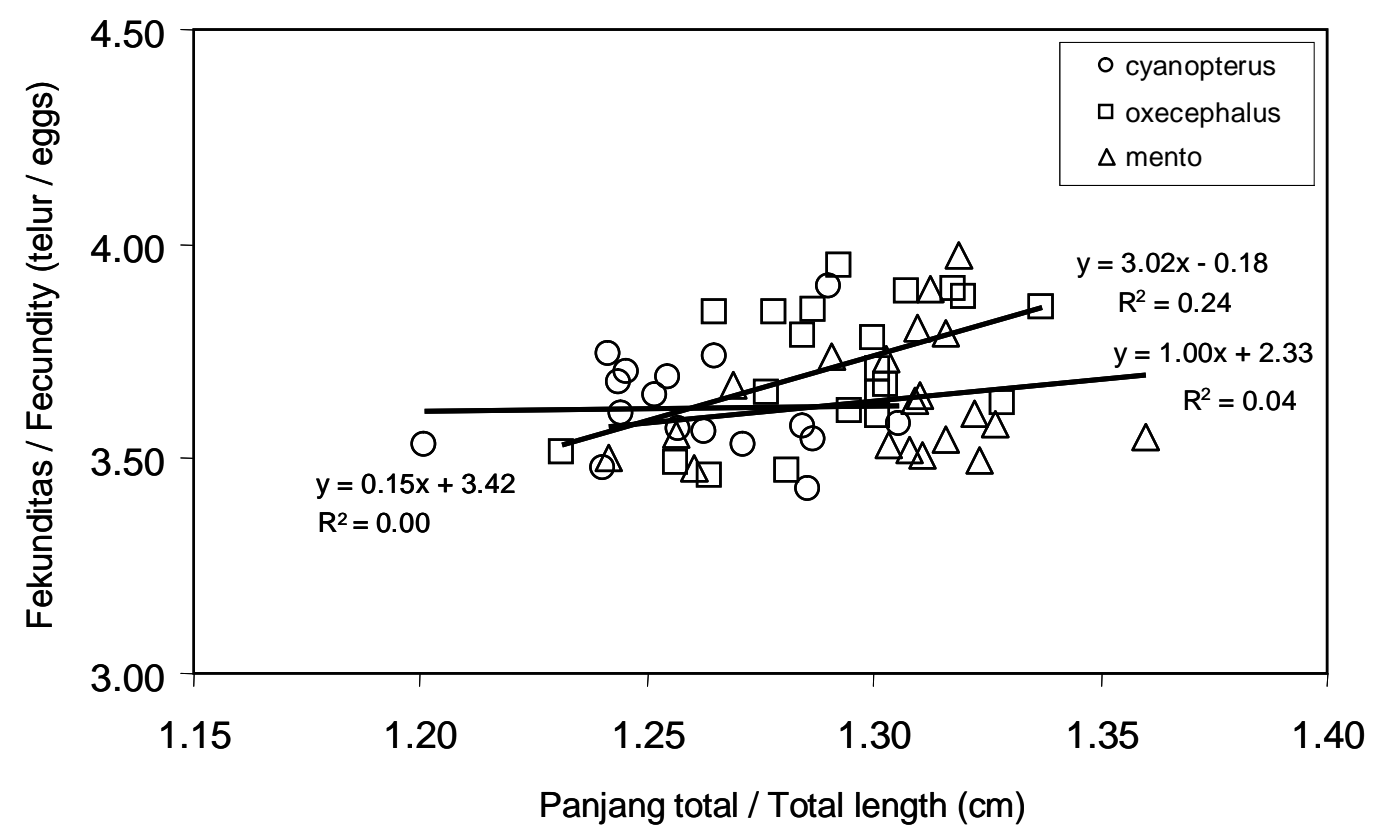

Gambar 3. Hubungan antara fekunditas (telur) dan panjang total $(\mathrm{cm})$ dari tiga jenis ikan terbang (data dalam log).

Figure 3. Relationships between fecundity (eggs) and total length $(\mathrm{cm})$ of three flyingfish species (data was transformed in logarithm).

Korelasi antara fekunditas dan bobot gonad diilustrasikan dalam Gambar 4. Terdapat korelasi positif yang mirip pada ketiga jenis ikan. Ini berarti jika bobot gonad bertambah, maka jumlah fekunditas juga meningkat. 


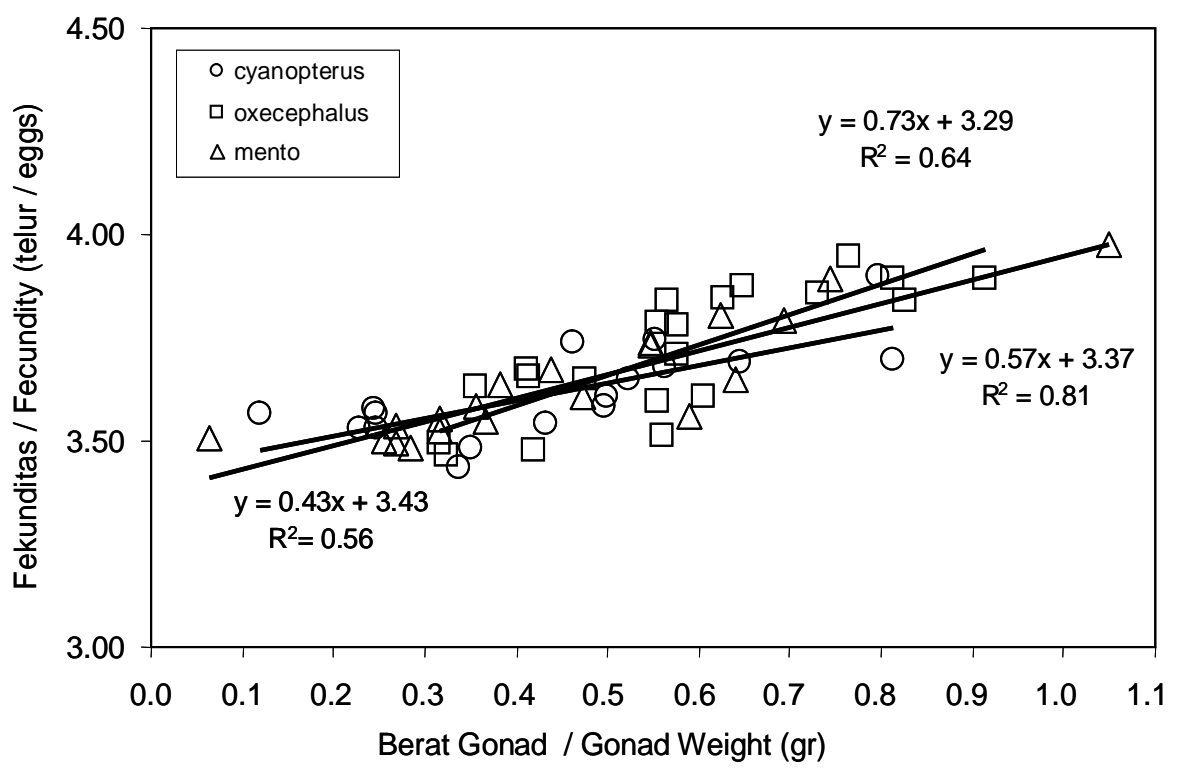

Gambar 4. Hubungan antara fekunditas dan bobot gonad dari tiga jenis ikan terbang (data dalam log). Figure 4. Relationships between fecundity (eggs) and gonad weight (gr) of three flyingfish species (data was transformed in logarithm).

\section{Diameter Telur}

Telur ikan terbang memiliki diameter pada tingkat kematangan gonad III antara selang 0,33-2,21 mm, sedangkan pada tingkat kematangan gonad IV antara 0,45-2,36 mm. Perbedaan ukuran diameter telur diduga merupakan strategi reproduksi ikan terbang untuk meningkatkan dan memperbanyak fekunditas dengan memperkecil diameter telur. Perubahan diameter telur kemungkinan juga merupakan respon dari perubahan lingkungan, perubahan genetik, serta pengaruh penangkapan (Ali \& Nessa, 2006), berikut diameter telur tiga spesies ikan terbang yang diamati pada (Tabel 3).

Tabel 3. Diameter telur $(\mathrm{mm})$ dari tiga jenis ikan terbang pada kondisi tingkat kematangan gonad III dan IV

Table 3. Egg diameter $(\mathrm{mm})$ of three flyingfish species at the third and fourth of gonad maturity stages

\begin{tabular}{lcccc}
\hline \multirow{2}{*}{ Jenis/Species } & TKG III/ & TKG IV/ & \multicolumn{2}{c}{ Rata-rata/Mean $(\mathbf{m m})$} \\
\cline { 4 - 5 } & Developed & Mature & TKG III/Developed & TKG IV/Mature \\
\hline Cheilopogon cyanopterus & $0,35-2,10$ & $0,45-2,25$ & 1,4913 & 1,8020 \\
Hirundichthys oxycephalus & $0,48-2,20$ & $0,38-2,21$ & 1,4823 & 1,8750 \\
Parexocoetus mento & $0,33-2,25$ & $0,50-2,36$ & 1,3154 & 1,5986 \\
\hline
\end{tabular}

Kajian ini merupakan studi karakteristik reproduksi dari ikan terbang di Indonesia. Dalam studi ini hanya diamati fekunditas dan diameter telur dari tiga jenis ikan terbang, yaitu Cheilopogon cyanopterus, Hirundichthys oxycephalus, dan Parexocoetus mento. Ketiga jenis ikan terbang ini merupakan jenis yang dominan dalam hasil tangkapan nelayan di perairan Takalar (Selat Makassar) dan perairan Pemuteran (Bali Utara) (Syahailatua, 2006; Syahailatua et al., 2008). Dengan demikian fokus pada studi ini hanya dilakukan pada tiga jenis ikan terbang, karena jumlah contoh ikan yang diperoleh dalam kondisi matang gonad cukup memadai.
Fekunditas, tingkat kematangan gonad, indeks kematangan gonad, diameter telur, serta panjang dan bobot ikan merupakan beberapa aspek biologi reproduksi ikan yang penting untuk diamati dan diketahui (Boer et al., 1996). Informasi mengenai tingkat kematangan gonad dapat dipergunakan untuk mengetahui waktu dan musim pemijahan yang tepat, sehingga dapat digunakan dalam pengaturan dan pengelolaan penangkapan perikanan di suatu wilayah (Dahuri, 2003), sedangkan fekunditas secara tidak langsung dapat dipergunakan untuk memperkirakan banyaknya ikan yang akan dihasilkan (Effendie, 2002). 
Masalah yang dihadapi perikanan ikan terbang adalah pemanfaatan telur yang semakin lama intensitasnya meningkat. Hal ini dikhawatirkan dapat berpengaruh terhadap proses rekruitmen larva ke dalam stok perikanan ikan terbang, karena adanya penurunan rekruitmen sehingga berdampak pada penurunan stok perikanan, dalam jangka waktu tertentu dengan tingkat eksploitasi yang terus meningkat, maka tidak hanya mengakibatkan penurunan jumlah populasi ikan, tetapi juga dapat menyebabkan kepunahan. Keuntungan ekonomis dari ikan terbang terutama adalah telurnya yang merupakan suatu peluang yang dimanfaatkan, karena dapat meningkatkan devisa dari sektor perikanan dan kelautan.

Selat Makassar dan perairan Singaraja, Bali merupakan salah satu daerah pemijahan dan penghasil ikan dan telur ikan terbang terbesar di Indonesia (Ali \& Nessa, 2006; Ali, 2005; Syahailatua et al., 2008). Daerah pemijahan merupakan daerah yang dilindungi di mana peraturan benar-benar efektif dan selektif. Pada daerah pemijahan penangkapan dapat dilakukan asalkan ikan-ikan yang tertangkap adalah ikan yang telah dewasa (telah melakukan pemijahan), sehingga proses rekruitmen dan ketersediaan stok dapat terus terjaga (Holden \& Raitt, 1974), dan kondisi tangkap lebih (over fishing) dapat dihindari.

Proses reproduksi yang menghasilkan keturunan baru (rekruitmen) akan mempengaruhi kelangsungan daur hidup ikan, besar dan kecilnya rekruitmen sangat ditentukan oleh jumlah telur yang dihasilkan dalam pemijahannya (fekunditas), semakin banyak ikan yang melakukan pemijahan maka anak ikan yang dihasilkan akan semakin banyak, sehingga kelangsungan proses daur hidup akan tetap terjaga (Effendie, 2002). Informasi mengenai tingkat kematangan gonad dan fekunditas ikan sangat penting bagi instansi terkait untuk menentukan kebijakan dalam pemanfaatan sumber daya perikanan, sehingga pemanfaatan dan pengelolaan sumber daya ikan terbang dapat berlangsung dengan optimal.

Tertangkapnya induk ikan disebabkan karena daerah penangkapan merupakan daerah pemijahan ikan, sehingga ikan-ikan yang melakukan pemijahan ikut tertangkap. Untuk mencegah tertangkapnya ikan yang sedang matang gonad atau sedang melakukan pemijahan dapat dilakukan dengan pengaturan waktu penangkapan, ukuran ikan yang ditangkap, alat tangkap, dan membuat sistem zonasi (Dahuri, 2003). Untuk menentukan pengaturan ini diperlukan informasi mengenai aspek biologi perikanan, beberapa aspek biologi ikan yang penting untuk diamati dan diketahui adalah tingkat kematangan gonad, jumlah telur yang dihasilkan atau fekunditas, diameter telur, serta panjang dan bobot (Boer et al., 1996).

Tipe pemijahan ikan terbang tergolong pada tipe pemijahan totalspawner, yaitu pemijahan berlangsung satu kali satu tahun, tetapi dalam waktu yang lama (tiga bulan), yaitu pada bulan Mei sampai Juli. Berdasarkan atas cara pemijahannya ikan terbang termasuk ke dalam golongan ikan phytopyls, yaitu ikan yang meletakan telurnya pada tumbuhan atau benda terapung (Nikolsky, 1963). Hasil penelitian Ali (1981) mengatakan bahwa ikan terbang memijah sekali satu tahun, dengan rata-rata diameter telur yang matang berkisar 1,49-1,79 mm akan dikeluarkan pada saat pemijahan.

Keuntungan yang diperoleh dari pemijahan total spawner adalah berhubungan dengan kelestarian populasi, di mana ikan terbang yang tertangkap memiliki ukuran relatif seragam, sehingga memungkinkan kemudahan dalam pengelolaan sumber daya perikanan. Hal ini berkaitan dengan waktu penangkapan yang diperbolehkan guna melindungi adanya penangkapan ikan terbang yang muda, sedangkan kerugiannya dapat dilihat dari jumlah stok ikan, oleh karena memijah sekali dalam satu tahun dikhawatirkan gagal rekruitmen, karena banyak faktor yang mempengaruhi di antaranya kematian pasca pemijahan (Ali, 2005), selain itu pengaruh dari predator yang banyak memangsa ikan terbang seperti ikan lumba-lumba (Dolphin sp.), tuna (Thunnus), cakalang (Katsuwonus pelamis), dan layaran (Istiophorus platypterus) (Moyle \& Cech, 2004).

Penelitian ini perlu dilanjutkan untuk memperoleh informasi tentang kecenderungan perubahan karakter reproduksi dari populasi ikan terbang. Hal-hal yang dapat mengakibatkan perubahan karakter reproduksi ini antara lain eksploitasi sumber daya perikanan ikan terbang yang berlebihan, degradasi habitat perairan, dan dampak perubahan iklim. Keterbatasan contoh gonad dari jenis ikan terbang yang sama dari beberapa lokasi memang merupakan kendala untuk dapat melakukan perbandingan antar populasi. Hal ini diakibatkan distribusi jenis ikan terbang di perairan Indonesia juga bervariasi (Syahailatua et al., 2009). Untuk itu, diperlukan strategi pengumpulan contoh ikan terbang secara rutin dari beberapa lokasi di perairan Indonesia, terutama untuk jenis yang menjadi sasaran eksploitasi telur ikan, seperti Hirundichthys oxycephalus. 


\section{KESIMPULAN}

1. Fekunditas setiap jenis ikan terbang bervariasi, namun miliki korekasi yang positif dengan panjang total dan bobot gonad.

2. Diameter telur ketiga jenis ikan terbang ini tidak menunjukan adanya perbedaan yang nyata, dan diameter telur pada ikan terbang dengan tingkat kematangan gonad IV lebih besar daripada tingkat kematangan gonad III.

3. Tertangkapnya ikan-ikan dengan kondisi siap memijah (tingkat kematangan gonad III dan IV) di lokasi penelitian ini mengindikasikan bahwa lokasi ini adalah lokasi pemijahan dan perlu dilindungi untuk kelestarian sumber daya perikanan ikan terbang.

\section{PERSANTUNAN}

Tulisan ini merupakan kontribusi dari kegiatan hasil riset perikanan ikan terbang dan prospek pengembangannya di Indonesia; fokus di Selat Makassar, Laut Flores, dan Laut Sulawesi, T. A. 20042006, di Lembaga IImu Pengetahuan Indonesia-Ancol, Jakarta. Sub Program: Sensus Biota Laut. Penulis mengucapkan terima kasih kepada Prof. Dr. Ir. S. A. Ali, M.Si. (Fakultas Ilmu Kelautan dan Perikanan, Universitas Hassanuddin) dan Ir. Retno Andamari, M.Sc. (Balai Besar Riset Perikanan Budi Daya Laut, Gondol), yang telah membantu mengumpulkan contoh ikan. Ucapan terima kasih disampaikan juga kepada John Picasouw, Rusli Rentua, dan Parino yang turut dalam penelitian lanjutan di laboratorium. Penghargaan disampaikan kepada Staf dosen dan rekan-rekan mahasiswa Fakultas Perikanan dan IImu Kelautan, Universitas Padjajaran yang sudah memberikan motivasi dan semangat untuk terlaksananya penelitian ini.

\section{DAFTAR PUSTAKA}

Ali, S. A. 1981. Kebiasaan makanan, pemijahan, hubungan bobot panjang, dan faktor kondisi ikan terbang, Cypselurus oxycephalus (Bleeker) di Laut Flores, Sulawesi Selatan. Tesis. Fakultas IImuilmu Pertanian. Universitas Hasanuddin. (Tidak Dipublikasikan). 49 pp.

Ali, S. A. 2005. Kondisi sediaan dan keragaman populasi ikan terbang, Hirundichthys oxycephalus (Bleeker, 1852) di Laut Flores dan Selat Makassar. Disertasi. Pascasarjana Universitas Hasanuddin. Makassar. (Tidak Dipublikasikan).
Ali, S. A. \& M. N. Nessa. 2006. Status ilmu pengetahuan ikan terbang di Indonesia. Dalam Omar et al. (eds). Prosiding Lokakarya Nasional Perikanan Ikan Terbang. Makassar. Tanggal 2021 September 2005. 16-37.

Boer, M., D. R. Monintja, \& S. Hariwisudo. 1996. Pengelolaan dan pemanfaatan sumber daya ikan di perairan Zona Ekonomi Ekslusif Indonesia. Jurnal IImu-IImu Perairan dan Perikanan Indonesia. IV (2): 65-78.

Dahuri, R. 2003. Keanekaragaman Hayati Laut Aset Pembangunan Berkelanjutan Indonesia. PT. Gramedia Pustaka Utama. Jakarta.

Effendie, M. I. 1979. Metode Biologi Perikanan. (Rev. Ed). Yayasan Dewi Sri. Bogor. vii+112.

Effendie, M. I. 2002. Biologi Perikanan. Yayasan Pustaka Nusantara. Yogyakarta.

Holden, M. J. \& D. F. S. Raitt. 1974. Manual of fisheries science. Part 2. Methods of Resource Investigation and Their Application. FAO Fisheries Technical Paper. 115. FAO. Rome.

Moyle, P. B. \& J. J. Cech, Jr. 2004. Fishes: An Introduction to Ichthyology. Prentice Hall. New Jersey.

Nikolsky, G. V. 1963. The Ecology of Fishes. Academic Press. London. 352 pp.

Sihotang, S. 2004. Pengembangan perikanan ikan terbang (Cypselurus spp.) di Sulawesi Selatan. Disertasi. Program Pasca Sarjana. Institut Pertanian Bogor. Bogor. (Tidak Dipublikasikan). $286 \mathrm{pp}$.

Syahailatua, A. 2006. Perikanan ikan terbang di Indonesia: Riset menuju pengelolaan. Oseana. XXXI (3):21-31.

Syahailatua, A., B. G. Hutubessy, F. Rijoly, \& H. Tuanaya. 2009 Komposisi jenis dan struktur ukuran ikan terbang di perairan Pulau Ambon, Maluku. Jurnal Oseanologi. 2 (1/2): 37-44.

Syahailatua, A., S. A. Ali, \& P. Makatipu. 2008. Strategi reproduksi ikan terbang (Exocoetidae) dan kaitannya dengan faktor oseanografi di perairan Indonesia. Jurnal Penelitian Perikanan Indonesia. 14 (3): 303-310. 